А.И. КРЮКОВ, Д.М.Н., профессор, Н.Л. КУНЕЛЬСКАЯ, Д.М.Н., профессор, А.В. ГУРОВ, д.М.Н., профессор, Г.Н. ИЗОТОВА, к.б.Н., А.Е. СТАРОСТИНА, А.С. ЛАПЧЕНКО

Научно-исследовательский клинический институт оториноларингологии им. Л.И. Свержевского Департамента здравоохранения г. Москвы

\title{
КЛИНИКО-МИКРОБИОЛОГИЧЕСКАЯ ХАРАКТЕРИСТИКА
}

\author{
ДИСБИОТИЧЕСКИХ ИЗМЕНЕНИЙ СЛИЗИСТОЙ ОБОЛОЧКИ \\ ПОЛОСТИ РТА И РОТОГЛОТКИ
}

\begin{abstract}
Дисбиоз ротовой полости и ротоглотки характеризуется снижением качественного и количественного состава микроорганизмов (бактерий, вирусов, грибов), в норме обитающих в ротовой полости, а также появлением других видов микроорганизмов, не характерных для данного биотопа. По данным зарубежных авторов, более чем 700 видов бактерий и других микроорганизмов обитают в ротовой полости человека, формируя сложные полимикробные ассоциации («биопленки») на различных биотических и абиотических поверхностях анатомических элементов, располагающихся в полости рта и ротоглотки $[1,2]$.
\end{abstract}

\section{Ключевые слова:}

дисбиоз, ротовая полость

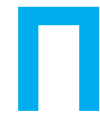

редставителями нормальной микрофлоры ротовой полости являются аэробные и анаэробные кокковые формы, непатогенные коринебактерии, спирохеты, молочнокислые бактерии, бактероиды и др. Индигенная микрофлора слизистой оболочки ротоглотки представлена $а$ - и $ү$-гемолитическими стрептококками. При этом титры микроорганизмов, колонизирующих данные биотопы у здорового человека, как правило, не превышают концентрации $10^{2}-$ $10^{3} \mathrm{KOE} / \mathrm{Mm}^{2}$. Однако в слюне и десневых карманах и слизистой оболочке ротоглотки вегетируют микроорганизмы в больших концентрациях (от $10^{5}$ до $10^{11} \mathrm{KOE} / \mathrm{Mл)}$ ). Данные микроорганизмы характеризуются преимущественно анаэробным типом метаболизма. Помимо этого, на слизистой оболочке ротоглотки и полости персистирует большое количество представителей транзиторной микрофлоры, которая представлена коагулазонегативными негемолитическими стафилококками, нейссериями, грибами рода Candida и др., количественный состав которых не постоянен и зависит от разнообразных факторов окружающей среды [3].

Возникновение активного воспалительного процесса, характеризующегося распространением инфекции в глубокие слои ткани, обусловлено, как правило, наличием различных предпосылок [4]. К ним относятся неправильное питание, нерациональная антибиотикотерапия, хронические заболевания органов пищеварения, гиповитаминоз, возраст, иммунодефицитные состояния. Особую роль отводят также состоянию окружающей среды, курению, наличию в полости рта протезных металлоконструкций и др.

В настоящее время дисбиозы считают основной причиной возникновения острых и хронических инфекцион- ных заболеваний верхних дыхательных путей, таких как ангина, острый фарингит, хронический тонзиллит, ларингит, синусит, евстахеит [5-9]. Быстрое возникновение и дальнейшее распространение воспалительного процесса в близлежащих органах обусловлено хорошей васкуляризацией и особенностями лимфооттока органов головы и шеи. Важно отметить также механизм иммунного воспаления органов ротовой полости и ротоглотки вследствие накопления продуктов жизнедеятельности, структурных элементов микробной клетки, высвобождающихся после ее гибели (эндотоксин), выступающих в роли антигена [4].

Дисбиозы слизистых оболочек, в т. ч. полости рта и ротоглотки, традиционно принято подразделять на четыре степени (по В.В.Хазановой) [10]: 1-я степень - дисбиотический сдвиг, при котором незначительно изменено количество одного вида условно-патогенного микроорганизма при сохранении нормального видового состава микрофлоры рта; такая форма называется латентной, или компенсированной, при этом выраженные клинические признаки заболевания отсутствуют; 2-я степень - субкомпенсированная форма: на фоне некоторого снижения титра лактобактерий выявляют 2-3 патогенных вида микроорганизмов; 3-я степень - субкомпенсированная форма: обнаружение патогенной монокультуры при резком снижении количества или полном отсутствии представителей индигенной (аутохтонной) микрофлоры; 4-я степень - декомпенсированная форма, которая характеризуется наличием ассоциаций патогенных видов бактерий с дрожжеподобными грибами, титр которых существенно превышает нормальные значения.

По другой классификации дисбиоз полости рта разделяют на 3 степени (Т.Л. Рединова, Л.А. Иванова, О.В. Мартюшева, Л.А. Чередникова, А.Б. Чередникова) [8].

В этом случае для 1-й степени характерно изменение в большую или меньшую сторону количества лактобацилл и коринебактерий при снижении количества других 
палочковидных форм (бактероидов, фузобактерий, лептотрихий), а также кокковой флоры (стрептококков, непатогенных стафилококков, вейлонелл, нейссерий) и грибов, при сохранении нормального титра условно-патогенных микроорганизмов (энтеробактерий), золотистого стафилококка. 2-я степень характеризуется значительными колебаниями уровня коагулазонегативных стафилококков, коринебактерий, бактероидов, фузобактерий и лептотрихий в сторону как снижения, так и повышения при резком снижении титра лактобацилл, вейлонелл, нейссерий и стрептококков, а также увеличением титра золотистого стафилококка и энтеробактерий при неизмененном количестве грибов рода Candida. При 3-й степени происходит снижение титра лактобацилл, стрептококков, вейлонелл, нейссерий; отмечаются резкие колебания состава бактероидов и коринебактерий. При этом значительно повышено количество золотистого стафилококка, коагулазонегативных стафилококков, энтеробактерий, фузобактерий, лептотрихий и грибов рода Candida.

Клиническая значимость данных классификаций состоит в том, что при развитии III-IV степени дисбактериозов неминуемо возникают грубые формы инфекционного процесса, зачастую приводящие к развитию осложнений. Именно поэтому крайне важным аспектом является профилактика развития выраженных форм дисбиотических изменений.

Симптомы дисбиоза ротовой полости и ротоглотки могут быть различными - жжение во рту, запах изо рта, неприятный привкус во рту, кариозные изменения зубов, воспаление и кровоточивость десен, наличие зубного «камня», появление трещин и сухости губ («заеды»), отек слизистой оболочки полости рта и носа, появление язв (афт), затруднение носового дыхания, заложенность носа, появления корок в носу, частых носовых кровотечений и др.

Проявления стоматита, пародонтоза, фарингитов, ангины, хронического тонзиллита, аденоидита у детей, ринита и синусита также часто являются следствием дисбиоза ротовой полости.

Важно отметить, что дисбиотические нарушения ротовой полости и ротоглотки как начального отдела пищеварительного тракта носят характер диссеминированного дисбактериоза, который, в свою очередь, проявляется воспалительными изменениями соматических органов и систем (ревматоидным артритом, миокардитом, нарушением работы пищеварительной системы, мочекаменной болезнью, атеросклерозом и др.) [4].

В возникновении патологических процессов на слизистой оболочке полости рта и ротоглотки существенную роль играют неспорообразующие облигатно-анаэробные микроорганизмы. При этом среди других бактерий наиболее часто высевают представителей семейства Prevotellaceae (Prevotella intermedia, Prevotella melaninogenica, Prevotella buccae, Prevotella oralis, Prevotella denticola), бактероиды Bacteroides pyogenes, Porphyromonas endodontalis, Fusobacterium nucleatum, а также штаммами Veillonella parvula, Atopobium rimae, Propionibacterium acnes, Peptostreptococcus anaerobius, Peptostreptococcus prevotii u Parviromonas micra.
В условиях формирования дисбиотических нарушений, обусловленных стойкой персистенцией данных микроорганизмов, часто развиваются гнойно-воспалительные заболевания, при этом характер течения патологического процесса всегда связан с биологическими свойствами возбудителя. Зная эти свойства, можно прогнозировать дальнейшее течение патологического процесса.

Так, превотеллы - грамотрицательные неспорообразующие бактерии, преимущественно обитающие в полости рта, толстом кишечнике и мочеполовом тракте, образуют достаточно токсичный ЛПС в сравнении с другими грамнегативными микрооранизмами, который может вызывать инфекционно-токсический шок. Данные микроорганизмы встречаются при развитии абсцедирующих поражений, могут вызывать гнойно-воспалительные заболевания мягких тканей челюстно-лицевой области, остеомиелит, поражения органов брюшной полости и мочеполового тракта [11].

Бактероиды - род грамотрицательных анаэробных бактерий, типичных обитателей кишечника человека и составляющих более половины его микрофлоры. Присутствуя в других областях организма человека, бактероиды могут стать причиной перитонита, абсцессов различной локализации, эндокардита, сепсиса, тонзиллита, периодонтита, различных воспалительных вмешательств после травм, инструментальных и оперативных вмешательств. Бактероиды вызывают более чем половину внутрибрюшинных анаэробных инфекций.

Porphyromonas endodontalis часто обнаруживается в составе микробных ассоциаций в инфицированных корнях зубов, в субмукозных микроабцессах эндодонтальной области, периодонтальных карманах, при некротических изменениях пульпы зуба. Данный микроорганизм в более чем половине случаев является причиной неудачного эндодонтического лечения [11].

Fusobacterium nucleatum - обитатель ротовой полости человека и доминирующий вид среди 400 видов бактерий зубной бляшки («камня», налета), вызывающий гингивиты и периодонтит. Штаммы Fusobacterium nucleatum могут проникать между стенками клеток кровеносных сосудов и, перемещаясь с кровотоком, достигать различных органов организма хозяина и формировать там свои колонии, что обусловливает длительные воспалительные процессы, образуя при этом атеросклеротические бляшки, эрозии костных структур. Это может приводить к воспалительным заболеваниям легких, мозга, печени, грудной клетки, абсцессам гинекологической области. Кроме того, Fusobacterium nucleatum играет важную роль провоцирующего инфекционного агента в развитии колоректальной карциномы [12].

Вейлонеллы - неспорообразующие кокковидные бактерии, входящие в состав нормальной микрофлоры человека, обитают в желудке человека. Однако при определенных условиях вейлонелла может быть кариесогенным микроорганизмом, который избирательно накапливается на поверхностях зубов, наиболее часто поражающихся кариесом (фиссуры и межзубные поверхности). Вейлонелла вырабатывает большое количество молочной кислоты, способствующей деминерализации кости и образованию микрополо- 
стей с последующей колонизацией другими микроорганизмами, что приводит к периодонтиту и периоститу.

Бактерии вида Atopobium rimae являются грампозитивными аспорогенными анаэробами, обитающими на деснах ротовой полости и часто выделяемыми при наличии хронического периодонтита. При определенных условиях могут стать причиной бактериемии и септического шока.

Выделенные штаммы Propionibacterium acnes - грамположительные анаэробные неподвижные бактерии главные возбудители акне человека. Они обитают в норме в глубине пор кожи человека и волосяных фолликулах, не вызывая воспалительных реакций у многих носителей. Однако при неблагоприятных условиях могут распространяться в другие анатомические зоны, вызывать блефарит, эндоофтальмит и другие гнойно-воспалительные заболевания глаз и приводить к потере зрения.

Пептострептококки (грамположительные неспорообразующие облигатные анаэробы - Peptostreptococcus anaerobius, Peptostreptococcus prevotii, представители нормофлоры желудочно-кишечного тракта) выделены из полостей абсцессов, деструктивных процессов в челюсти, паратонзиллярных абсцессов, а также при одонтогенном сепсисе и эндокардите. При опеределенных условиях могут вызывать воспалительные изменения в лимфоидной ткани.

Parviromonas micra - грамположительный аспорогенный периодонтальный патоген ротовой полости, способный к росту и пролиферации внутри биопленок и способствующий воспалению десен, костной потери альвеолярного отростка и мобильности зубов. При иммуносупрессии и травматических повреждениях данный микроорганизм способен к генерализации с развитием абсцессов легких, эмпиемы, аспирационной пневмонии, медиастинита, инфекционных процессов головного мозга и селезенки.

Помимо облигатно-анаэробных микроорганизмов, воспалительные процессы слизистой оболочки полости рта и ротоглотки способны вызывать и грамположительные и грамотрицательные аспорогенные факультативные анаэробы: стафилококки, стрептококки, энтеробактерии, гемофильную бактерию. При этом традиционно лидирует стрептококковая и стафилокковая флора.

Стафилококки могут быть представлены как коагула30-отрицательными штаммами: Staphylococcus epidermidis, Staphylococcus warneri, Staphylococcus capitis, Staphylococcus hominis, Staphylococcus haemolyticus, Staphylococcus lentus, Staphylococcus haemolyticus, так и коагулазо-положительным Staphylococcus aureus.

Стафилококки - это группа микробных агентов, способных вызывать более сотни различных болезней, в любой системе органов, в любом виде ткани. Это уникальное свойство связано с наличием огромного комплекса факторов патогенности (адгезивных, факторов агрессии, экзотоксинов, аллергезирующих факторов, факторов, индуцирующих выработку антител и развитие аутоиммунных реакций, факторов, угнетающих фагоцитоз, энтеротоксинов). Они играют одну из ведущих ролей в развитии и течении риносинусита, ларингита и фарингита.

Госпитальные штаммы золотистого стафилококка ответственны за многие заболевания и раневые инфек- ции в стационарах. Основным резервуаром золотистого стафилококка является полость носа и полость рта, но он может также встречаться и в гортани, анатомических карманах слизистой оболочки, на волосистой части эпидермиса и в желудочно-кишечном тракте $[17,18]$.

В ряде случаев высевают также микроорганизмы рода Gemella. Чаще других видов - Gemella morbillorum и Gemella haemolysans - род грамвариабельных аспорогенных неподвижных бактерий, относящихся к семейству стафилококков и обитающих в мукозных мембранах ротовой полости и пищеварительного тракта. Gemella способна вызывать кистозный фиброз, различную легочную патологию и эндокардит.

Среди условно-патогенных и патогенных видов стрептококков флоры у обследованных пациентов всегда преобладают а-гемолитические $S$. pneumoniae, а также $\beta$-гемолитические S. pyogenes, S. anginosus u S. constellatus. Среди $\gamma$-гемолитических стрептококков чаще высевают энтерококки. С данными бактериями связано развитие острых и хронических заболеваний полости рта, параназальных синусов, среднего уха, а также острой и хронической тонзиллярной патологии.

Слизистая оболочка полости рта и ротоглотки является первым (проксимальным) биотопом человеческого организма, где встречаются представители семейства энтеробактерий: Enterobacter spp., Hafnia spp., Proteus spp., Klebsiella spp., Serratia spp., а также Escherichia coli и др.

Энтеробактерии являются причинами множества заболеваний человека. Распространение Escherichia coli может вызывать инфекции желудочно-кишечного тракта с выраженной клинической симптоматикой (интоксикацией, лихорадкой, диареей и др.), геморрагический колит, гемолитико-уремический синдром, инфекции мочевыводящих и желчевыводящих путей, септические осложнения. Klebsiella - возбудитель пневмонии, инфекции мочевыводящих путей, заболеваний глаз, суставов, мозговых оболочек и легочного сепсиса.

Важную роль среди бактерий с факультативно-анаэробным типом метаболизма играет также Haemophilus influenzae.

Аэробный спектр бактерий чаще представлен грамотрицательными микроорганизмами: Pseudomonas aeruginosa, Pseudomonas sturzeri, Moraxella catarrhalis u Achromobacter xylosoxidans.

Персистенция гемофильной палочки часто характеризуется стойким течением патологического процесса, выраженными инфильтративными изменениями слизистой оболочки, приводящими к нарушениям ее функции и хронизации процесса в дальнейшем.

Haemophilus influenzae и Moraxella catarrhalis являются ведущими патогенами целого ряда заболеваний. Они вызывают инфекции как верхних (острый средний отит, синусит), так и нижних (пневмония, бронхит, обострение хронического обструктивного заболевания легких) дыхательных путей. Кроме того, данные возбудители могут вызывать опасные для жизни состояния (менингит, сепсис, остеомиелит и др.).

Pseudomonas aeruginosa, или синегнойная палочка, вызывает до 20\% всех внутригоспитальных, или назоко- 
миальных, инфекций, до 35\% инфекций мочевыделительной системы и 25\% гнойных хирургических процессов. В основном встречается у лиц с ослабленным иммунитетом и наличием сопутствующих инфекций. Наиболее часто вегетирует на поверхности эпидермиса слухового прохода и полостях среднего уха в условиях хронического воспаления. При ее распространении может происходить развитие гастроэнтероколита, аппендицита, холецистита. Синегнойная палочка устойчива ко многим антисептическим препаратам и часто переносится контактным путем через плохо дезинфицированные санузлы, руки медицинского персонала, медицинские инструменты $[17,18]$.

Грибковая микрофлора чаще всего бывает представлена родом Candida, наиболее часто выделяемым условным патогеном ротовой полости. Очень часто данные микроорганизмы высевают у пациентов с наличием каких-либо иммунодефицитных состояний на фоне соматических заболеваний (сахарный диабет и др.), а также при наличии инородного тела в верхнечелюстной пазухе (пломбировочный материал). При этом грибковые патогены в ротовой полости часто ассоциированы с микробными агентами и формируют стойкие грибково-бактериальные ассоциации.

Наиболее часто встречается ассоциирование грибов со стафилококками, стрептококками, протеем, нейссериями. При этом наиболее неблагоприятными считаются ассоциации грибов рода Candida с патогенными видами стафилококков [4]. Наличие таких грибково-микробных ассоциаций значительно усложняет лечение дисбиоза ротовой полости и ротоглотки.

Нередко в условиях формирования дисбиотических изменений высевают также актиномицеты: Actinomyces oris, Actinomyces odontolyticus, Actinomyces naeslundi, среди которых наиболее часто всречается A. odontolyticus. Актиномицеты - сапрофиты человека, род грамположительных факультативных анаэробных бактерий, способных к образованию мицелия и атипичных форм воспаления, связанного с образованием гранулематозных очагов - друз. Актиномицеты обнаруживаются в полости рта, в тонзиллярных «проб- ках», кариесогенных зубных полостях, верхних дыхательных путях, бронхах, желудочно-кишечном тракте. Они присутствуют в десневых карманах и могут быть причиной абсцессов мягких тканей ротовой полости, желудочно-кишечного тракта или легких. Наличие актиномицетов часто связано с наличием свищевых ходов у пациентов.

Необходимо помнить, что формирующиеся на фоне дисбиозов слизистых оболочек тонзиллит, фарингит, ринит, синусит, а также ларингит, в силу близкого топографического расположения, могут вызывать генерализацию процесса с быстрым распространением инфекции на соседние анатомические структуры, вызывая тем самым комплексное воспаление верхних дыхательных путей, внутричерепные осложнения и сепсис. Поэтому своевременное местное лечение первичного очага воспалительного процесса и коррекция дисбиоза полости рта и ротоглотки как входных ворот инфекции помогают предотвратить дальнейшее ее распространение. Лечение дисбактериоза полости рта обязательно включает в себя санацию ротовой полости. В комплексной терапии дисбиоза ротовой полости и ротоглотки применяют следующие группы препаратов: местные антисептики; антибиотики и противомикробные препараты, эубиотики, местные препараты микробных лизатов, а также витамины.

При этом применение антисептических лекарственных препаратов - одна из первостепенных задач врачебной тактики при лечении воспалительных процессов полости рта и ротоглотки [15]. Для местного лечения дисбиоза полости рта и ротоглотки часто используют различные антисептики в виде полосканий, спреев, таблеток для рассасывания.

Обобщая все вышеизложенное, необходимо отметить, что восстановление микроэкологии ротовой полости и ротоглотки и борьба с микробными и грибковыми патогенами, вегетирующими на слизистой оболочке, имеют важное значение в устранении дальнейшего распространения множества ассоциированных между собой микроорганизмов, предотвращая, таким образом, генерализацию и хронизацию возникших очагов дисбиотических процессов.

\section{ЛИТЕРАТУРА}

1. Aas JA, Paster BJ, Stokes LN, Olsen I, Dewhirst FE. Defining the normal bacterial flora of the oral cavity. J Clin Microbiol, 2005, 43: 5721-32.

2. Nath SG, Raveendran R. Microbial dysbiosis in periodontitis. J Indian Soc Periodontol, $2013 \mathrm{JuL}$ Aug, 17(4): 543-545.

3. Топчий Н.В. Проблема дисбиоза в общей врачебной (семейной) практике. Фарматека, 2007, 8/9.

4. Гуров А.В., Поливода А.М., Полякова Т.С. Современный взгляд на проблему терапии тонзиллофарингитов. РМЖ, 2007, 15(2): 146.

5. Годовалов А.П., Быкова Л.П., Шипилина Е.Д., Некоторые особенности лабораторной диагностики дисбиотических состояний полости рта. В мире научных открытий, 2010, 4(10), часть 14: 7-8.

6. Бондаренко В.М., Воробьев А.А. Дисбиозы и препараты с пробиотической функцией. Журн. микробиол., 2004, 1: 84-92.

7. Давыдова Т.Р., Карасенков Я.Н., Хавкина Е.Ю К проблеме дисбиоза в стоматологической практике. Стоматология, 2001, 80(2): 23-24.

8. Редилова Т.Л., Иванова Л.А., Мартюшева О.В. и др. Микробиологические и клинические характеристики дисбиотического состояния в полости рта. Стоматология, 2009, 6: 12-18.

9. Савичук Ю.Н., Савичук А.В. Микроэкология полости рта, дисбактериоз и пути его коррекции. Современная стоматология, 2002, 4: 9-12.

10. Хазанова В.В., Рабинович И.М., Земская Е.А., Рабинович О.Ф., Дмитриева Н.А. Изучение микробиоценоза при хронических заболеваниях слизистой оболочки полости рта. Стоматология. 1996, 75(2): 26.

11. Gomes BP, Jacinto RC, Pinheiro ET, Sousa EL, Zaia AA, Ferraz CC, Souza-Filho FJ. Porphyromonas gingivalis, Porphyromonas endodontalis, Prevotella intermedia and Prevotella nigrescens in endodontic lesions detected by culture and by PCR. Oral Microbiol Immunol, 2005 Aug, 20(4): 211-5.

12. Castellarin M, Warren RL, Freeman JD, Dreolini L, Krzywinski M, Strauss J, Barnes R, Watson P Allen-Vercoe E, Moore RA, Holt RA. Fusobacterium nucleatum infection is prevalent in human colorectal carcinoma. Genome Res., 2012 Feb, 22(2): 299-306.

13. Angelakis E. Human Case of Atopobium rimae Bacteremia. Emerging Infectious Diseases, 2009, 15(2): 354-355.
14. Gorospe L, Bermudez-Coronel-Prats I, GomezBarbosa CF, Olmedo-Garcia ME, Ruedas-Lopez A, Gomez del Olmo V. Parvimonas micra chest wall abscess following transthoracic lung needle biopsy. Korean J Intern Med., 2014 Nov, 29(6): 834-837.

15. Кириченко И.М., Клиническая эффективность и безопасность применения препарата мирамистин раствор для местного применения $(0,01 \%)$ у детей, страдающих обострением хронического тонзиллита и/или острым фарингитом. Практическая медицина, Педиатрия, 2011, 5: 11. 16. Zabolotnyy DI et al. Treating of chronic pharyngitis at the stage of aggravation: clinical, immunological and microbiological aspects. Zdorovja Ukraini. The Medical Journal, 2007, 19(176): 1-3.

17. Пальчун В.Т., Кафарская Л.И., Полякова Т.С., Гуров А.В. Динамическое исследование антибиотикорезистентности микробного фона в оториноларингологическом отделении. Вестник оториноларингологии, 2004, 1: 53.

18. Пальчун В.Т., Кафарская Л.И., Гуров А.В. Проблема госпитальной инфекции в условиях ЛОР-стационара. Вестник оториноларингологии, 2005, 6: 4-9. 